\title{
Psicoterapia de grupo para parejas como modelo de intervención en un instituto de tercer nivel
}

\author{
Claudia Sánchez Bravo, ' Jorge Carreño Meléndez, ${ }^{1}$ Alejandra Watty Martínez, ${ }^{1}$ \\ Alba lvette Belmont Sánchez ${ }^{2}$
}

Artículo original

\section{SUMMARY}

At the National Institute of Perinatology, a line of clinical psychological research is the study and treatment of patients with couple problems to generate strategies of intervention based on clinical research.

\section{Objective}

To identify risk indicators in a psychotherapy institutional group process.

\section{Material and method}

The qualitative-interpretative method was used. The sessions, in an open group form, were once a week during two hours. Attendance ranged between eight and 12 participants. 35 sessions were analyzed with the content analysis method.

\section{Results}

The mean age was 32.3 years for women and 35.1 for men. The information was systematized with the most significant stories. The indicators found in women were: impotence and trapping feelings, affective distancing from their couple, confusion of the origin of the relationship conflicts between external and/or internal origins, violent or confused communication, submissive or explosive character, resentment due to a perceived indifference from their couple, history of sexual abuse which difficults a satisfactory development of couple relationships, guilt, and resentment or anger feelings at their parents. The indicators in men were: trapping and impotence feelings due to the control exercised by their couples, violent behaviors on domestic environments, over-exigent and persecutory conducts, difficulty on the individuation process and unsolved conflicts with their primary figures which prevent a satisfactory relationship.

\section{Conclusions}

Marital problems deeply disturb the affective life of people and have familiar and social consequences. This paper is an incursion to understand a small part of the important facts regarding this universe, aiming to be more specific in the treatment plans for people suffering marital conflicts.

Key words: Couple problems, group psychotherapy, risk indicators.

\section{RESUMEN}

Una línea de investigación clínica de Psicología en el Instituto Nacional de Perinatología, es el estudio y atención a las pacientes con problema de pareja, para generar estrategias de intervención basadas en la investigación clínica.

\section{Objetivo}

Detectar indicadores de riesgo en un proceso de psicoterapia de grupo institucional.

\section{Material y método}

Se utilizó el método cualitativo-interpretativo. Las sesiones se llevan a cabo una vez a la semana, con dos horas de duración, en grupo abierto, con una fluctuación de entre ocho y 12 participantes. Se analizaron 35 sesiones con análisis de contenido.

\section{Resultados}

La edad promedio fue de 32.3 años para las mujeres y de 35.1 para los hombres, la sistematización de la información obtenida se realizó con las partes de los relatos más significativos. Algunos indicadores encontrados en las mujeres fueron: sensación de impotencia y atrapamiento, distanciamiento afectivo de su pareja, confusión al no ubicar si los conflictos en la relación son externos o internos, la comunicación es violenta o confusa, o son sumisas o son explosivas, hay resentimiento por percibir indiferencia de su pareja, hay relatos de abuso sexual que dificulta un desarrollo satisfactorio de la vida en pareja, culpa, resentimientos e ira hacia sus padres. En los hombres hay atrapamiento e impotencia por un control desmedido que ejerce su pareja hacia ellos, ejercen actos violentos en el ámbito doméstico, son muy exigentes y persecutorios, con dificultad en el proceso de individuación, conflictos no resueltos con sus figuras primarias, imposibilitan una relación satisfactoria.

\section{Conclusiones}

Los problemas maritales afectan profundamente la vida afectiva de las personas con consecuencias familiares y sociales. Este trabajo es una incursión para entender una pequeña parte de lo que incluye este universo y poder ser más específicos en los planes de tratamiento de las personas que sufren conflictos maritales.

Palabras clave: Problema de pareja, psicoterapia de grupo, indicadores de riesgo.

1 Departamento de Psicología del Instituto Nacional de Perinatología (INPer), México.

2 Comisión Coordinadora de Institutos Nacionales de Salud y Hospitales de Alta Especialidad (CCINSHAE), México.

Correspondencia: Dr. Jorge Carreño Meléndez. INPer. Montes Urales 800, Torre de Investigación, ler piso, Lomas Virreyes, 11000 , México, DF. Tel. 5520-9900 Ext. 147. E-mail: jocame2003@yahoo.com

Recibido primera versión: 21 de julio de 2011. Segunda versión: 26 de abril de 2012. Aceptado: 15 de febrero de 2013. 


\section{INTRODUCCIÓN}

En las últimas décadas y con el desarrollo innegable de la investigación dentro del campo de la psicología, uno de los mayores retos es la aplicación de los hallazgos en la práctica clínica. Dentro de las instituciones de salud no psiquiátricas la población que asiste para su atención clínica no está exenta de presentar, además del problema médico, problemas psicológicos que pueden entorpecer su tratamiento, por lo que la propuesta es brindar una atención integral acorde con las necesidades particulares de la población que se atiende en cada institución.

Esta propuesta concreta surge en el Departamento de Psicología del Instituto Nacional de Perinatología "Isidro Espinosa de los Reyes" (INPer), institución dedicada a la solución de problemas reproductivos y perinatales. La investigación psicológica que se realiza en la institución tiene, como tarea fundamental, dar atención clínica a aquellas pacientes que lo requieran. Mediante la atención y la observación clínica surgen líneas de investigación, mismas que, al desarrollarse y sobre la base de hallazgos, arrojan resultados que permitan generar estrategias de intervención, lo que desde luego da una mayor especificidad para contribuir a una alta calidad en la atención clínica psicológica, pues la investigación clínica debe tener como fin último mejorar la calidad en la intervención.

Dentro de los programas y las líneas de investigación se abordan los Problemas de Parejas y Sexualidad Humana, los cuales surgen por la alta demanda de las pacientes con quejas en esta área. El trabajo en este programa abarca dos planos: el primero consiste en dar asistencia a todas aquellas pacientes que reconozcan como problema psicológico principal los conflictos de pareja; el segundo, que de esa atención clínica surjan protocolos de investigación. La asistencia a las pacientes, a sus parejas, o a ambos, consta del diagnóstico y el plan de tratamiento, esto es, su incorporación a un grupo de psicoterapia en instituciones, el cual funciona como un grupo abierto de manera permanente. Éste es para pacientes que lo requieran, independientemente del problema reproductivo por el que ingresaron al INPer.

Con los avances de la Psicología en el campo de la salud, una de las formas más difundidas de intervención es la psicoterapia de grupo institucional como método para resolver conflictos psicológicos, que pueden ir de leves a graves, y que impactan su calidad de vida, o bien que presenten algún trastorno mental o de personalidad diagnosticado según los criterios del DSM-IV-TR ${ }^{1}$ y que requieran tratamientos combinados (además de la psicoterapia de grupo, el tratamiento psiquiátrico u otro paralelo, como en el caso de las adicciones). También es una modalidad de tratamiento para las parejas que presentan problemas psicológicos y de interacción y que son agravados o provocados por el problema de salud. El grupo de parejas es de utilidad para analizar los modelos insatisfactorios que cada uno de los integrantes ha introyectado en el pasado y cómo interactúan en su situación actual, adquiriendo características propias.

\section{OBJETIVO}

Detectar indicadores de riesgo relacionados con la presencia de insatisfacción marital manifestada en la problemática de pareja, durante su participación en un proceso de psicoterapia de grupo en instituciones, como una opción de tratamiento psicológico que se da en el servicio de Psicología del INPer a los pacientes que lo requieran, a la par de su tratamiento médico.

Los objetivos específicos son:

1. Identificar indicadores actuales, tanto internos - generados por la propia dinámica de pareja - como externos - generados por otros sistemas familiares - que influyen en la presencia de problemas de pareja.

2. Identificar indicadores que influyeron en el desarrollo insatisfactorio de su vida en pareja.

3. Identificar elementos situados dentro de la dinámica familiar nuclear de cada uno y que impactan su vida actual de pareja.

Ahora bien, es importante establecer cuál es el campo dentro de la psicología de la salud del cual partimos para la atención de pacientes que requieren tratamiento psicológico, por lo que se propone la siguiente definición: Es la rama de la psicología que se encarga de investigar, diagnosticar y tratar todas las alteraciones psicológicas que tienen que ver con la construcción de la vida psíquica del individuo y su interacción con el mundo social (subjetividad), y que pueden manifestarse en procesos que van desde reacciones emocionales normales hasta procesos psicopatológicos instalados durante la construcción de su vida psíquica, desde épocas tempranas de su vida y que no son provocadas por alteraciones fisiológicas u orgánicas. ${ }^{2}$

\section{MATERIAL Y MÉTODO}

Se utilizó el método cualitativo-interpretativo, exploratorio. Los estudios cualitativos se centran en los procesos y no en las conductas aisladas; este enfoque de la investigación nos permite dar cuenta de la complejidad que representa la interacción de valores culturales, normas sociales, así como experiencias familiares e individuales en la vida de la pareja. ${ }^{3}$

\section{Contexto}

El escenario es la cámara de Gesell del Departamento de Psicología del INPer, servicio especial de la institución, con un grupo abierto que funciona de manera permanente por la demanda de los pacientes. Este tipo de grupo incorpora a los nuevos miembros en el trabajo grupal favoreciendo un mayor avance, 
con el siguiente encuadre: sesiones una vez a la semana con una duración de dos horas, dirigido por un psicoterapeuta (cuya tarea institucional consiste en desarrollar el programa llamado de sexualidad humana y parejas a tres niveles: asistencia - en el cual se da el tratamiento grupal - enseñanza e investigación), con la asistencia de entre 10 y 14 participantes.

\section{Participantes}

Las pacientes, algunas de ellas con su pareja, son dirigidas al Servicio de Psicología por tres vías: la primera, a solicitud de ellas mismas; la segunda, por haberse detectado en algún otro servicio alguna problemática psicológica y, tercera, por ser detectadas en alguno de los protocolos de investigación de este programa y que, además de su participación en la investigación, requieran de asistencia clínica. Todas deben cubrir los siguientes criterios de inclusión:

1. Ser pacientes del INPer, a partir de los 22 años de edad.

2. Que el motivo de consulta principal de envío al servicio de Psicología sea el referir, como principal problema psicológico, el de los conflictos de pareja, independientemente de los motivos por los que está en la institución.

3. Que tengan como mínimo un año de vivir en pareja, independientemente del estado civil.

4. Que de presentar un trastorno grave de la personalidad o un trastorno mental, además de los problemas psicológicos y de pareja, acepte la interconsulta en el servicio de psiquiatría o neurología o en un servicio externo para recibir un tratamiento integral.

5. Son aceptadas las parejas, pero también se aceptan a todas aquellas(os) pacientes que cubren los criterios de inclusión pero que por diversas circunstancias la pareja no puede o no quiere asistir al grupo.

\section{Procedimiento}

El Departamento de Psicología realiza una historia clínica, con diagnóstico, pronóstico y plan de tratamiento con derivación de pacientes al grupo de psicoterapia. Se les entrega, conforme a los requerimientos éticos institucionales, la carta de consentimiento informado y se recaba su aprobación para registrar de manera escrita el desarrollo de cada una de las sesiones grupales por el observador de la cámara de Geslel. Los pacientes (mujeres y hombres) son candidatos al grupo de parejas por su disposición para realizar un trabajo psicoterapéutico donde se combina tanto el encuadre como la técnica grupal. ${ }^{4}$

\section{Psicoterapia de grupo en instituciones}

En el INPer el tratamiento mediante la psicoterapia de grupo ha demostrado ser una modalidad eficiente y práctica; la elección y exploración de este modelo de trabajo institucional se prefiere por varios factores: la demanda por parte de las pacientes, el tiempo de trabajo institucional y el económico. ${ }^{5}$ La eficacia de la psicoterapia de grupo estriba en la importancia que tienen las interacciones interpersonales en el desarrollo psicológico. ${ }^{6}$ Es una herramienta eficaz dirigida hacia la comprensión y corrección de las distorsiones interpersonales, pero también para el manejo de los conflictos psicológicos centrados fundamentalmente, en este grupo, en la relación de pareja, abordando aspectos que han sido obtenidos en investigaciones realizadas en esta línea y que tiene como objetivo principal trabajar con los elementos insatisfactorios que cada uno de los integrantes percibe y expresa, así como con algunos elementos introyectados en el pasado y que interactúan de una u otra manera en la relación de pareja actual, adquiriendo características propias que potencializan algunos procesos psicopatológicos (que causan dolor y sufrimiento) y son parte de la interacción. La técnica empleada es la de psicoterapia de grupo, la cual concibe al grupo como una totalidad, sin minimizar los elementos individuales que deben contemplarse dentro del proceso grupal y que el psicoterapeuta aborda con la libertad de también hacer intervenciones a cada miembro del grupo, sin perder la mirada del proceso grupal. ${ }^{7,8} \mathrm{La}$ utilización de esta herramienta psicológica ha permitido la atención de pacientes de diversos padecimientos que tienen un denominador común: los problemas de pareja, pero que presentan también conflictos y alteraciones psicológicas. Éstos pueden tener múltiples manifestaciones y aunque puedan parecer similares tienen una etiología distinta. La intensidad de los síntomas, al igual que la duración y la frecuencia pueden ser diferentes. Estos conflictos pueden provenir del pasado o del presente y caber o no en una clasificación de los trastornos mentales o de los trastornos de la personalidad. Es en este terreno donde entran los planes terapéuticos con tratamientos combinados para algunos pacientes, que requieren, además de la psicoterapia de grupo, atención psiquiátrica o neurológica o bien un tratamiento paralelo en grupos especiales, como en el caso de las adicciones.

\section{Ejes del trabajo terapéutico}

La valoración del terapeuta, después de rastrear el conflicto, es en dos planos:

1. Sucede en la realidad.

2. Se interpreta de la realidad.

La intervención es a varios niveles:

1. Estructurar a la pareja.

2. Trabajar con la dinámica.

3. Analizar cada sesión grupal de manera global, pero trabajando también los focos más significativos de los integrantes.

Meta:

Reintegrar a la pareja o lograr una separación menos destructiva, con una diferenciación más clara, pasando de las acusaciones a la reflexión. 


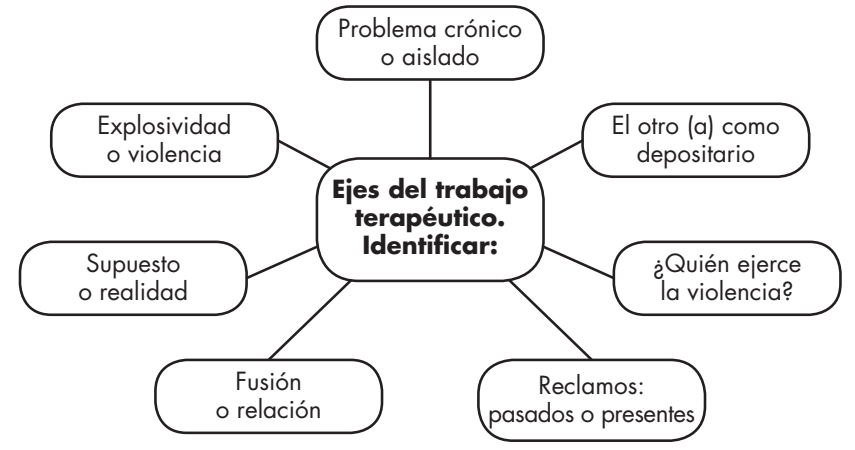

\section{Dispositivos metodológicos}

Se analizaron 35 sesiones grupales en un periodo de seis meses, las cuales se trabajaron con el análisis de contenido para la identificación de indicadores de cada sesión, basado en la guía temática de los objetivos específicos que son el resultado de la saturación de tres aspectos: los teóricos, detectados en las investigaciones sistematizadas de la problemática de pareja; ${ }^{9}$ los observados en la práctica clínica institucional y la iteración de indicadores de las participantes, de donde surgieron las categorías contempladas.

\section{Plan del análisis de la información}

El análisis de contenido se utilizó con una orientación empírica y exploratoria para categorizar lo más importante y repetido de cada sesión. La estrategia metodológica se realizó conceptualizando y ordenando las ideas, las cuales se organizaron respetando dos normas básicas: ${ }^{10}$ a) se empieza con un sistema abierto de categorías, texto de campo, y b) se elabora un segundo texto, directo, del contenido manifiesto, e inferencial del contenido latente. La sistematización se realizó dividiendo las unidades de análisis por cada participante en la sesión y las partes de los relatos más significativos de cada objetivo específico. Las categorías se consideraron a partir de la jerarquía que los participantes les dieron dentro del proceso grupal, focalizando los conflictos de pareja, de lo que está sucediendo actualmente, de lo que sucedió en la construcción de su vida juntos y en el impacto de su dinámica familiar nuclear en su vida actual, además de detectar los relatos donde hay confusión y que pueden mostrar, más un problema con su mundo interno vertido en la pareja, que un problema real con el otro. El análisis final consistió en la ubicación de las conexiones esenciales con el objeto de estudio, detectando los indicadores de riesgo más relevantes. ${ }^{11}$

\section{RESULTADOS}

\section{Descripción de los participantes}

Para la descripción de la muestra de participantes se tomaron los factores sociodemográficos de los asistentes en la
Cuadro 1. Motivo de ingreso

\begin{tabular}{lc}
\hline Referidas por & \% Parejas \\
\hline Ginecología & 47.0 \\
Climaterio & 23.6 \\
Obstetricia & 14.7 \\
Infertilidad & 14.7 \\
\hline
\end{tabular}

etapa del proceso grupal en que fueron evaluadas las 35 sesiones, puesto que éste es un grupo abierto y que funciona de manera permanente en el INPer. El promedio de edad fue de 32.3 para las mujeres y de 35.1 para los hombres, con una asistencia de entre 10 y 14 pacientes, y un porcentaje de $60 \%$ de mujeres y $40 \%$ de hombres (cuadros 1 y 2 ).

\section{Obtención de datos}

\section{Primer objetivo: \\ Indicadores actuales tanto internos como externos que influyen en la presencia de problemas de pareja (ver ANEXO 1) \\ Mujeres}

En los distintos relatos predominaron factores relacionados con acusaciones a la pareja, el reclamo es constante y cargado de resentimiento y odio. Predomina la sensación de impotencia, de atrapamiento e incapacidad para encontrar la forma de cambiar el estado actual de la relación; son relatos en los que se trasluce el distanciamiento afectivo que perciben las mujeres respecto de sus parejas y que ha llevado paulatinamente a la fractura de la relación sin que se expliquen sus causas. Prevalece la confusión al no lograr ubicar si los conflictos son únicamente externos y provocados sólo por las parejas o hay factores internos en ellas que propician o complican la relación; se sienten sumidas en una contradicción entre querer dejar a la pareja, con fantasías de venganza, y no poder hacerlo, y su reacción conductual, a veces cargada de explosividad, que obedece a esta confusión. Otro elemento significativo es que la comunicación con la pareja genera mayor confusión y tensión por tener un estilo de comunicación violento o confuso, ${ }^{12}$ cargado de resentimiento, lo cual se establece de manera cotidiana, tornándose casi en la única forma de interacción, donde la excepción se convierte en regla, lo que desde luego representa un riesgo para la integridad mental de cada miembro de la pareja y de los hijos. El hecho de vivir con esa carga afectiva consume gran parte de su energía, impidiéndoles prácticamente te-

Cuadro 2. Escolaridad

\begin{tabular}{lrc}
\hline Escolaridad & Mujeres & Hombres \\
\hline Primaria & $2.9 \%$ & $8.3 \%$ \\
Secundaria & $29.4 \%$ & $8.3 \%$ \\
Preparatoria & $50.0 \%$ & $58.4 \%$ \\
Licenciatura & $14.8 \%$ & $25.0 \%$ \\
Posgrado & $2.9 \%$ & $0.0 \%$ \\
\hline
\end{tabular}


ner áreas libres de conflicto, y si las hubiese, se encuentran paralizadas y soterradas, sobre todo las que tienen que ver con el desarrollo personal, pues otro factor repetidamente encontrado es la obstaculización de la pareja ante los deseos de desarrollo personal de las mujeres. Actúan como si este deseo pusiera en riesgo la estabilidad y bienestar familiar, por lo que ellas se sienten utilizadas por ellos. Ante esto, sus respuestas son polarizadas, hay tanto pasividad y sumisión como explosividad, recursos poco eficaces para lograr cambios, algunas veces por la paralización misma y otras porque no tienen los recursos psicológicos para hacerlo, manifestando la dependencia hacia esta relación-fusión, con incapacidad para diferenciarse del otro, quedando paulatinamente borradas, depositando su insatisfacción en lo que no le da el otro, con la percepción de ser manipuladas a través de la culpa.

\section{Hombres}

Se observa una polarización en sus respuestas, aunque distintas a la de las mujeres los relatos denotan un atrapamiento e impotencia por percibir un control desmedido ejercido por sus parejas, refiriendo reclamos repetidos acompañados de reacciones explosivas que los llevan a tomar una distancia afectiva y sexual, ${ }^{13}$ por lo que una parte de su vida es inaccesible y desconocida para ellas. Esto es un campo fértil para la fantasía y tiene como consecuencia hacer suposiciones que se confunden con la realidad. También hay relatos donde manifiestan ejercer actos violentos hacia su pareja para dominarla, por el temor que les genera perder el control sobre ellas y los hijos, tratando de restringirlas al ámbito doméstico y dejando ver su angustia e inseguridad ante la posibilidad del crecimiento de ellas fuera del hogar, lo cual viven como amenazante. Hay insatisfacción y frustración personal convertida en ira y descargada en la pareja, o ignorándola o descalificándola.

\section{Segundo objetivo: \\ Identificar indicadores, que hayan influido en el desarrollo satisfactorio/insatisfactorio de su vida en pareja (ver ANEXO 2)}

\section{Mujeres}

En los relatos se observa falta de flexibilidad para renegociar o modificar roles, el resentimiento las ha endurecido, perciben de su pareja indiferencia hacia su sufrimiento, lo cual las llena de enojo por la forma de vida que han construido. Los conflictos se han ido empantanando paulatinamente pues, en lugar de resolverlos, se distancian, como una defensa a las tensiones cotidianas, o se pelean, lo cual incrementa la distancia; se sienten anuladas y utilizadas, la forma en que se han comunicado ha sido violenta y confusa. Este círculo que se forma y que va del distanciamiento al pleito, como una forma cotidiana de vida, aumenta el vacío y da pie a los supuestos, a la interpretación de la conducta del otro, dando por hecho algo que es producto del desconocimiento de lo que en realidad sucede, pues no hay diálogo, y el dar como realidad un supuesto favorece las conductas erráticas que complican la relación. Uno de los supuestos encontrados es la certeza de que, para su pareja, ni la relación ni sus sentimientos ni su sufrimiento son importantes, lo que desencadena conductas destructivas y autodestructivas. Hay relatos donde ellas se borran ante el dominio irracional de su pareja y relatos donde aparece un tercero (el saber de una infidelidad o la intromisión constante de alguien de la familia, etc. $)^{14}$ que detona o incrementa los conflictos. Esto indica, por un lado, la fractura entre ellos y, por otro, que la situación se utiliza para excluirlas u hostilizarlas.

\section{Hombres}

Adoptar una nueva forma de vida, al tener una pareja, les implica dificultad a la renuncia de modelos anteriores, de ahí que tratan de combinar dos formas de vida (soltero y casado), lo que genera caos; este es un campo propicio para la sobreinterpretación, los celos y el enojo de la pareja. Otro elemento encontrado es la utilización de la rutina casera para atacar a la pareja; ésta es una forma sutil de violencia psicológica, una sobre exigencia irracional, en vez de hacer, exigen, convirtiéndose en seres persecutorios.

\section{Tercer objetivo: \\ Identificar elementos que dentro de la dinámica familiar nuclear impactaron o impactan su vida actual de pareja (ver ANEXO 3) \\ Mujeres}

En los relatos se observa una alta frecuencia de abuso sexual en la infancia y la adolescencia. Desde luego, hay distintos tipos de abuso sexual; no obstante, siempre hay una condición de abuso, pues es ejercido por alguien con poder sobre la niña o adolescente, y este hecho tiene impacto en el desarrollo psicológico. Con el propósito de encontrar especificidad, hay situaciones de mayor gravedad, complicadas con otros elementos que implican muchos más riesgos, como que sea realizado por una persona cercana y conocida de la familia o cuando es un familiar, lo cual puede convertirse en abuso sexual e incesto y más aun cuando los padres o alguna autoridad, conociendo la situación, culpen, descalifiquen o ignoren a la víctima, sin hacer nada para remediar esta situación o se conduzcan como cómplices del abuso. Una complicación más es que se establezca como parte de una rutina diaria por un tiempo considerable y que esté complicada con violencia física. Una de las repercusiones en la edad adulta es la presencia de sentimientos encontrados, que son contradictorios y que muchas veces impiden que haya un desarrollo satisfactorio de la vida en pareja, no sólo en el terreno sexual sino en el afectivo, donde muestran culpa hacia lo que sucedió, combinada con resentimientos e ira hacia sus figuras parentales y desplazada muchas veces a su relación actual de pareja. Otro elemento encontrado es una identificación con las partes sufrientes de su madre, lo que impide el desarrollo de 
su propia vida, saboteando sus satisfactores en vías de no traicionar el estilo de vida materno. Se observa la necesidad de pelear, con discusiones interminables, sin fundamento real, y cuya aparente intención es la de exponer sus puntos de vista y necesidades actuales, con una sobrecarga afectiva que no corresponde a los hechos actuales, lo que impide el acercamiento afectivo y la satisfacción conyugal. Los motivos de su enojo son vagos o inexistentes, es todo y es nada, relatos confusos sin una focalización clara del conflicto con la pareja, por lo que o lo asfixian con el acoso o lo satanizan, pero no se relacionan; anulan sus cualidades, sólo existe lo destructivo; una relación que puede ser una fuente potencial de placer y satisfacción la convierten en una fuente de sufrimiento y frustración.

\section{Hombres}

Hay dificultad en el proceso de individuación que los lleva a dividir su mundo en dos partes, donde la jerarquía mayor la tiene su familia de origen. Se observa una dificultad para diferenciarse del padre, temor a enfrentarlo, a defender las diferencias, no hay un proceso adecuado de individuación. Tienen la percepción del padre violento, sin embargo repiten ese modelo en su vida actual de pareja. Los conflictos no resueltos con sus figuras primarias imposibilitan una relación satisfactoria con la pareja, con dificultad de demostrar sus sentimientos por temor a que abusen de ellos, el control y la agresión a la pareja son el reflejo del daño causado en su núcleo familiar primario.

\section{CONCLUSIONES}

Hay dos grandes grupos de conflictos; el primero se genera a partir de una falla en la estructuración de la pareja, por un proceso de individuación inacabado, problemas derivados de la incrustación de la pareja en un sistema familiar ya formado, donde toda la dinámica de este añejo complejo familiar inunda a la pareja impidiéndole construir su relación. Por tanto, la identificación de sus propios conflictos y afectos están contaminados por la familia extendida. El segundo grupo está dado por los que se dan por problemas en la vida afectiva de la pareja y que forman parte de la propia dinámica y en los que hay que diferenciar entre los conflictos de su mundo interno y los que son producto de la interacción con la pareja, para evitar que la cronificación de los conflictos invadan todas las áreas de vida, paralizando sus posibilidades de cambio y crecimiento personal.

Cabe destacar que en los relatos de los hombres hay momentos de reflexión que los llevan a detener su estallido verbal y a criticar sus sensaciones internas con reconocimiento de sus errores, deseando la reparación. Es más frecuente que en el hombre se manifieste la angustia a través de conductas persecutorias y en la mujer con conductas erráticas o desorganizadas.

\section{DISCUSIÓN}

En la construcción de la relación de pareja se conjugan múltiples mundos: individuales, familiares y los que la propia relación genera. El hecho de tener problemas maritales afecta profundamente la vida afectiva de las personas, además de provocar consecuencias familiares graves que repercuten en el ámbito social. El tratar de entender este complejo mundo es tarea esencial del psicólogo de la salud. Este trabajo es una incursión en el mundo de la pareja para entender una pequeña parte de lo que incluye este universo y poder ser más específicos en los planes de tratamiento de las personas que sufren tales conflictos maritales. El caos en la pareja se manifiesta cuando se observa la incapacidad de distinguir lo destructivo de lo constructivo, no se reconocen cualidades, no hay diferencia entre cualidad o defecto, ni entre querer y cuidar o no querer y descuidar, ya no se distingue entre egoísmo o generosidad o entre amor u odio y se convierten así en depositarios de sus fantasmas. ${ }^{15}$ Las parejas acuden a psicoterapia o piden apoyo psicológico puesto que saben que tienen problemas pero no saben cómo resolverlos o se convierten en una masa de reclamos, sin distinción ni jerarquización, ni ubicación clara de los conflictos: dónde están; qué los provocó; son míos, son de él, son de los dos; están en el mundo externo o en el mundo interno; son los otros. Hay una confusión que los lleva a sentirse atrapados en los conflictos, que aumenta la ansiedad desorganizándolos más, además de impactar negativamente en su satisfacción, no sólo marital sino existencial. Es necesario decir que este trabajo es una pequeña muestra de lo que se trabaja en un grupo terapéutico cuyos problemas prioritarios son los problemas de pareja, esto es una de sus limitaciones pues los pacientes que asisten a la institución tienen características específicas que sólo serían representativas de poblaciones con características similares. Otra limitante es que no todos asisten en pareja, algunas veces asiste sólo un miembro, y aunque el trabajo que se realiza en un grupo va a impactar a todo el entorno, en este grupo el avance sería mayor si asisten los dos. Otro factor en contra son los problemas que se desencadenan por su estado de salud, pues ésta es un institución que acepta pacientes con riesgo reproductivo y muchas veces tienen que interrumpir su trabajo psicoterapéutico por el cuidado de su salud; la ventaja es que la psicoterapia de grupo aplicada en las instituciones de salud no psiquiátricas es una herramienta útil, como propuesta institucional, para ofrecer a los pacientes una atención integral.

\section{REFERENCIAS}

1. American Psychiatric Association. Manual Diagnóstico y Estadístico de los Trastornos Mentales (DSM-IV-TR). Madrid: Masson; 2002.

2. Sánchez BC, Carreño MJ. Guía clínica de intervención psicológica de la sexualidad humana en parejas. Revista Perinatología Reproducción Humana 2007;21:33-43. 
3. Tarrés ML. Observar, escuchar y comprender sobre la tradición cualitativa en la investigación social. México: Miguel Ángel Porrúa; 2004.

4. González NJ. Psicoterapia de grupos: Teoría y técnica a partir de diferentes escuelas psicológicas. México: El Manual Moderno; 1999.

5. Fiorini H. Teoría y técnica de psicoterapias. Buenos Aires: Nueva Visión; 1992.

6. Vinagradov S, Yalom ID. Guía breve de psicoterapia de grupo. Barcelona: Paidós; 1996.

7. Colli AM, Lorenzo M. Psicoterapia de grupo: revisión histórica. Rev Hosp Psiquiátrico Habana 2004;1(1):2-3.

8. Grinberg L, Sor D, Tabak de Bianchedi. Introducción a las ideas de Bion. Buenos Aires: Nueva Visión; 1973.

9. Balcazar NP, González-Arriata NI, Gurrola PGM, Moysén A. Investigación cualitativa. México: Universidad Nacional Autónoma del Estado de México; 2006.
10. Ruíz OJ. Metodología de la investigación cualitativa. España: Universidad de Deusto; 1996.

11. Mejía R, Sandoval SA. Tras las vetas de la investigación cualitativa. Perspectivas y acercamientos desde la práctica. México: ITESO; 2009.

12. Sánchez BC, Carreño MJ, Martínez RS, Gómez LME. Comunicación marital y estilo de comunicación en mujeres con disfunción sexual. Revista Perinatología Reproducción Humana 2003;17:91-101.

13. Labrador FJ, Crespo M. Tratamientos psicológicos eficaces para las disfunciones sexuales. Psicothema 2001;13(3):428-441.

14. Rubio E, Díaz J. Las disfunciones sexuales. Citado en CONAPO (ed.) Antología de la sexualidad humana. México: Miguel Angel Porrúa; 1994.

15. Vargas B, Diaz-Loving R, Reyes I. Círculo de violencia: ¿se puede romper? Revista Psicología Social Personalidad 2008;XXIV(2):163-178.

Artículo sin conflicto de intereses 
ANEXO 1

Primer objetivo: Indicadores actuales tanto internos como externos que influyen en la presencia de problemas de pareja

\begin{tabular}{|c|c|}
\hline \multicolumn{2}{|r|}{ Mujeres } \\
\hline Elementos encontrados & Unidades de análisis y relatos \\
\hline \multicolumn{2}{|c|}{ Categoría 1. Fallas en la integración de pareja, anulación del otro(a) } \\
\hline Impotencia, desesperanza & $\begin{array}{l}\text { Mi esposo siempre deja todo a medias, nunca termina nada, yo estoy luchando, él no lucha, se la pasa viendo } \\
\text { la tele, ya vi que la relación no va a cambiar. El hombre en ocasiones no tiene sensibilidad para percibir las } \\
\text { labores domésticas. }\end{array}$ \\
\hline Impotencia & Mi marido en los problemas familiares nunca hace nada, siempre me deja todo a mí. \\
\hline Distanciamiento afectivo & $\begin{array}{l}\text { Nuestro problema básico es que no podemos integrarnos como pareja, él está muy distante, no encuentro la } \\
\text { manera de poderme acercar a él, la terapia creo que nos ha servido individualmente pero falta como pareja. }\end{array}$ \\
\hline \multicolumn{2}{|c|}{ Categoría 2. La relación como una forma de atrapamiento } \\
\hline Control y manipulación & $\begin{array}{l}\text { Le propuse que quería entrar a trabajar, él se enojó muchísimo, luego ya se calmó y ahora ya hasta hace todo } \\
\text { lo que yo quiero, me dio mi domingo, me compra todo. }\end{array}$ \\
\hline Control & $\begin{array}{l}\text { Ayer mi pareja me intentó tratar mal pero lo mande a la fregada, el no quiere que lleve al niño a la guardería. } \\
\text { Piensa que nadie lo va a cuidar como yo. }\end{array}$ \\
\hline $\begin{array}{l}\text { Contradicciones, } \\
\text { confusión, agresión } \\
\text { sexual y afectiva }\end{array}$ & $\begin{array}{l}\text { Nuestra relación es muy buena, pero desde el bebé las cosas cambiaron. Tuve que dejar de trabajar, fue un shock. } \\
\text { Problemas en el trabajo, económicos, estaba agotada emocionalmente. Depender de un hombre al cien por ciento } \\
\text { me afectó. Mi bebé es todo, no puedo dejarlo solo. Pedirle dinero es muy humillante para mí. Me contagió una } \\
\text { enfermedad venérea. Soy muy aprensiva y sobreprotectora. Indiferencia de él hacia mi persona en el ámbito } \\
\text { sexual. Me produce nauseas que se me acerque. }\end{array}$ \\
\hline $\begin{array}{l}\text { Distanciamiento, } \\
\text { atrapamiento, temores }\end{array}$ & $\begin{array}{l}\text { Somos indiferentes y no podemos dialogar, no me tiene ni le tengo confianza, me debilita, le pedí que se vaya } \\
\text { pero no me pela, este distanciamiento me genera miedo, soledad, me siento muy dependiente, he dejado de gol- } \\
\text { pear a mi hijo pero él busca provocarme, estoy con él no se si por dependencia, hace dos semanas entré en una } \\
\text { depresión muy fuerte, volví a pensar en el suicidio y no sólo yo sino llevarme a mi hijo e inclusive a mi esposo. }\end{array}$ \\
\hline \multicolumn{2}{|c|}{ Categoría 3. La violencia como una forma de vida } \\
\hline Manipulación y dominio & $\begin{array}{l}\text { Quiero ser independiente, sé que económicamente no soy solvente y veo que es una forma de dominio hacia } \\
\text { mí. Es una forma inconsciente de lastimarme, de demostrarme que tiene poder, me controla con el dinero para } \\
\text { las consultas, sé cuanto gana pero no sé en que lo gaste. Lo he estado pensando mucho, analizando ventajas } \\
\text { y desventajas y creo que estaríamos mejor sin él, de todos modos los niños no lo ven y como pareja ya no } \\
\text { llenamos las necesidades de cada uno, nos estamos destruyendo mutuamente, el no quiere, yo siento mucho } \\
\text { rencor, coraje y resentimiento. Que no me pisotee, si quiere tener las amigas o las parrandas, no me importa. } \\
\text { Aunque vaya con él a mí no me pela. Me hace sentir culpable de todo. }\end{array}$ \\
\hline $\begin{array}{l}\text { Explosividad, } \\
\text { atrapamiento }\end{array}$ & $\begin{array}{l}\text { Me pasaba lo mismo con mi pareja, siempre yo tenía que ocuparme de los niños, se lo mencioné y poco a poco } \\
\text { empezó a entenderlo. Hace dos semanas mi hijo hizo una travesura en casa de mis suegros y él me dijo "Cierra } \\
\text { la puerta", me molesté y empaqué para irme porque no voy a permitirle su maltrato, él en la pelea se bajó del } \\
\text { coche yo le dije que no hiciera esos circos enfrente de la niña tuve que ser agresiva para que él reaccionara. }\end{array}$ \\
\hline $\begin{array}{l}\text { Indiferencia, impotencia, } \\
\text { atrapamiento }\end{array}$ & $\begin{array}{l}\text { Él es muy agresivo, llegué a la indiferencia, en diciembre me defendí en vez de darle el avión con la cena de } \\
\text { navidad. Él empezó a tomar, manejó, discutimos, llegamos tarde a la cena, discutimos en el brindis y empe- } \\
\text { zaron a regañarlo (su hermano) traía pistola y yo no me había dado cuenta. Me insultó y me golpeó, todos } \\
\text { reaccionaron a mi favor, correspondí la agresión, sigo con él no puedo dejarlo. }\end{array}$ \\
\hline $\begin{array}{l}\text { Explosividad, } \\
\text { rechazo sexual }\end{array}$ & $\begin{array}{l}\text { Él se quedó en el coche porque veníamos discutiendo, ya no hay golpes pero sigue con sus vulgaridades, discu- } \\
\text { timos porque no le dije donde pararse, y de ahí derivaron insultos y amenazas, mencionó que él solo viene aquí } \\
\text { para ayudarme, porque yo soy una pinche histérica. En la intimidad estamos muy mal, él piensa que yo tengo } \\
\text { que provocarlo, los problemas han bajado pero explota y se pone mal, en la intimidad me siento rechazada. }\end{array}$ \\
\hline Confusión, ambivalencia & $\begin{array}{l}\text { Él me denigraba, pensé en huir, siempre deseaba que él me buscara, al regresar la situación era peor, empecé } \\
\text { a contestar la agresión, me amenazaba con suicidarse, yo siempre regresaba. }\end{array}$ \\
\hline Fantasías de venganza & $\begin{array}{l}\text { Tengo sed de venganza. Ya no quiero volver a ser la niñita sobreprotegida de mi familia, no nos estamos que- } \\
\text { dando juntos él me dice que estoy gorda y fea. }\end{array}$ \\
\hline \multicolumn{2}{|c|}{ Categoría 4. Vínculo a través del pleito o discusión cotidiana } \\
\hline $\begin{array}{l}\text { Aislamiento, dominio, } \\
\text { sometimiento }\end{array}$ & $\begin{array}{l}\text { A cada momento me dicen que no se hacer las cosas, que no me organizo supuestamente, ya me separó de amista- } \\
\text { des y familiares. Por que siempre soy yo, desorganizada cochina y no puedo hablar con él y eso es diario. Ahorita } \\
\text { está el problema con mi hijo que me dice que se quiere suicidar, el es un niño promedio pero él le dice que es un }\end{array}$ \\
\hline
\end{tabular}




\section{ANEXO 1 (continuación)}

\begin{tabular}{|c|c|}
\hline & $\begin{array}{l}\text { cochino desordenado, que me falta ponerle límites, pero yo lo veo bien como un niño cualquiera. Yo sufro violencia } \\
\text { económica de muchos tipos. Hace mucho tiempo yo me quise suicidar con mis dos hijos. Yo no me daba a basto y } \\
\text { llegué a creer que era todo lo que él me decía. Nunca lo complazco. Hay un pleito diario y a todas horas me recla- } \\
\text { ma, es un pleito diario al tratar de poner límites, siempre estamos peleando, peleando y peleando. }\end{array}$ \\
\hline \multicolumn{2}{|c|}{ Categoría 5. Ruptura de límites, fractura en la pareja } \\
\hline $\begin{array}{l}\text { Infidelidad masculina, } \\
\text { provocación, escape }\end{array}$ & $\begin{array}{l}\text { Mi esposo tiene una prima que se le insinúa mucho, me da coraje que me quieran ver la cara de mensa, no } \\
\text { siento celos, me da coraje que no me quiere dejar. No me deja hacer nada ni siquiera ir a mis cursos, yo } \\
\text { dependo mucho de él porque no tengo familia. Cuando nos peleamos nos golpeamos, le he dicho que no me } \\
\text { pegue en la cara, donde sea menos en la cara porque me hierve la sangre. }\end{array}$ \\
\hline $\begin{array}{l}\text { Exclusión, infidelidad } \\
\text { masculina }\end{array}$ & $\begin{array}{l}\text { Fue el cumpleaños de mi marido y me pidió que le hiciera una comida, llegaron los amigos, él me excluyó y } \\
\text { atendió a la secretaria, ya tomados él manosea a su tía y yo lo descubro, me dio mucho coraje, desde entonces } \\
\text { tengo vómito, ya no quiero estar con él. }\end{array}$ \\
\hline $\begin{array}{l}\text { Infidelidad femenina, } \\
\text { culpa }\end{array}$ & $\begin{array}{l}\text { No tengo tranquilidad, no puedo dormir no puedo dejar a mi amante, mi esposo y yo estamos durmiendo } \\
\text { separados y a los hijos les miento con el propósito de disculparme ante ellos, somos pareja sin serlo. }\end{array}$ \\
\hline \multicolumn{2}{|c|}{ Categoría 6. Utilización del sexo para agredir } \\
\hline $\begin{array}{l}\text { Distanciamiento afectivo, } \\
\text { agresión sexual, } \\
\text { devaluación }\end{array}$ & $\begin{array}{l}\text { Si yo no busco al señor no hay nada, o aunque lo busque siempre tiene pretextos, él dice que estoy enferma } \\
\text { de sexo, si él no se acerca yo tampoco, está pegado a los negocios, ya no sale con los amigos, pero aunque } \\
\text { está ahí no hay relaciones, yo le pido que tengamos relaciones, me dice enferma, pero tenemos una cada tres } \\
\text { meses, no puedo tocar ese tema, ya me dijo que si no me parece que no sea pendeja y que me busque otro. }\end{array}$ \\
\hline \multicolumn{2}{|c|}{ Categoría 7. La rutina utilizada como una forma de violencia } \\
\hline $\begin{array}{l}\text { Barreras para el } \\
\text { acercamiento afectivo }\end{array}$ & $\begin{array}{l}\text { Lo siento muy obsesivo con la casa, tiene que estar bien todo y si queda tiempo después nosotros. De lunes a } \\
\text { domingo es la casa. Es nuestro conflicto, quiere tener su casa impecable. }\end{array}$ \\
\hline $\begin{array}{l}\text { Celoso, persecutorio, } \\
\text { dominante }\end{array}$ & $\begin{array}{l}\text { A él no le gusta que alguien este sin hacer nada, yo le sugiero que viva y deje vivir, esto lo convierte en una } \\
\text { persona agresiva con los demás, la niña lo ha notado, mi hijo mayor le tiene miedo, también dice que no lo } \\
\text { tomo en cuenta para separar a los niños de recamara, además es con el fin de que sus familiares ni los míos } \\
\text { vean que hay una recamara vacía. También me molesta mucho su desconfianza e inseguridad, el domingo vio } \\
\text { a un hombre con quien yo salía hace muchos años, el no dijo nada pero siempre aprovecha la oportunidad } \\
\text { para decirme ahí viene tu novio, sus celos infundados me hacen sentir muy mal. }\end{array}$ \\
\hline Dominio & $\begin{array}{l}\text { Me di cuenta que me hace falta como amigo y pareja. En diciembre, a pesar de la operación de mi madre, } \\
\text { asistí a la cena con su mamá, sentí coraje porque me domina, esto me hace reflexionar hacia dónde queremos } \\
\text { llegar y el daño que nos hacemos. }\end{array}$ \\
\hline $\begin{array}{l}\text { Estrategias de } \\
\text { manipulación, dominio }\end{array}$ & $\begin{array}{l}\text { Ayer, hablaba con R. y me decía algo muy cierto que yo así había sido educada, que siempre quiero tener la } \\
\text { razón, que trato de hacer mi voluntad, que hago drama para que todo el mundo lo vea como yo lo veo y esto } \\
\text { me cayó como balde de agua. }\end{array}$ \\
\hline Necesidad de dominio & $\begin{array}{l}\text { Él es el que checa la escuela de mi hijo, hace poco le decía que fuéramos a la escuela y nos peleamos y él } \\
\text { me decía que yo no confiaba en él y peleábamos, yo siento que él está en su zona de confort, no hace nada } \\
\text { y cuando le digo nos peleamos. Yo cocino, lavo y lo hago con mucho gusto, yo me he esforzado para eso } \\
\text { por mi casa y mis hijos. Él se quedó sin trabajo y está al pendiente de todo lo que hago, es como si tuviera un } \\
\text { supervisor en la casa, nos vamos a quedar sin familia. }\end{array}$ \\
\hline \multicolumn{2}{|c|}{ Categoría 8. La violencia de pareja depositada en los hijos } \\
\hline $\begin{array}{l}\text { Distanciamiento afectivo, } \\
\text { discriminación, sumisión }\end{array}$ & $\begin{array}{l}\text { Siento que no es importante platicarlo, pero a mí me duele, mi esposo es blanco y uno de mis hijos tiene mi } \\
\text { tez y es agredido por mi esposo, él y yo le tenemos miedo, ya tenemos cuatro años con esto, se ha querido ir } \\
\text { a vivir con su abuelita. }\end{array}$ \\
\hline $\begin{array}{l}\text { Pasividad masculina, } \\
\text { desplazamiento } \\
\text { a los hijos }\end{array}$ & $\begin{array}{l}\text { Mientras yo cambiaba al bebé él se tardó y me molesta llegar tarde, él me dijo que nada más me la pasaba } \\
\text { chingando, el problema es su lentitud. ¡Hombre deberías de ser para sacar esta situación adelante y no yo! En } \\
\text { la mañana hasta con el niño me desquité, le dije que el me tiene así, me dijo además "no te desquicies". No } \\
\text { trata de hacer nada, siempre maquilla la situación, es un desgraciado, llevamos dos meses sin tener relaciones, } \\
\text { seguimos sin dinero y él no cobra. }\end{array}$ \\
\hline
\end{tabular}


ANEXO 1 (continuación)

\begin{tabular}{|c|c|}
\hline \multicolumn{2}{|r|}{ Hombres } \\
\hline Elementos encontrados & Unidades de análisis y relatos \\
\hline \multicolumn{2}{|c|}{ Categoría 1. Necesidad de someter al otro } \\
\hline $\begin{array}{l}\text { Culpa y necesidad } \\
\text { de control }\end{array}$ & Me siento mal, cuando oigo que la mujer trabaja, no me gusta que me manden. \\
\hline Necesidad de control & $\begin{array}{l}\text { Algo que me hicieron ver sin que me dijeran y que me acabo de dar cuenta es lo impositivo que soy, siento } \\
\text { aberración contra la mujer que trabaja, me doy cuenta que someto a mi señora. }\end{array}$ \\
\hline \multicolumn{2}{|c|}{ Categoría 2. Percepción de estilo autoritario y controlador de la otra } \\
\hline $\begin{array}{l}\text { Sobreexigencia, } \\
\text { acoso, devaluación }\end{array}$ & $\begin{array}{l}\text { Me enojo porque ella se enoja, la razón del pleito fue la tapa del biberón, ella magnifica todo, me atosiga, me } \\
\text { observa para ver en qué la riego, dice que soy un bruto, un pendejo, es tajante, no escucha, yo las normas las hago } \\
\text { muy flexibles. }\end{array}$ \\
\hline Necesidad de control & $\begin{array}{l}\text { El domingo salimos a comprar zapatos para nuestro hijo, pero al no ponernos de acuerdo no compramos nada, } \\
\text { a ella no le gusta mi punto de vista, a veces me siento controlado. }\end{array}$ \\
\hline Imposición (de la otra) & $\begin{array}{l}\text { No me casé para que me dominara con imposición, ya no tomo en exceso ni llego tarde, por razonamiento y a } \\
\text { petición de ella, he empezado a sentir que tengo que estar con mi hijo en lugar de estar con amigos, no llego a } \\
\text { casa con aliento alcohólico, el quererme hacer cambiar es una imposición, la siento como un eterno juez, he sido } \\
\text { en efecto necio, de no querer poner orden, yo síllevo una doble vida, una vida en el trabajo, otra en mi casa, no } \\
\text { me gusta contarle cosas porque las cuestiona, en mi trabajo mi estilo de resolver problemas es otra cosa, con ella } \\
\text { es imposición, no digo nada, soy sarcástico, soy lacerante y prefiero omitir muchas cosas para no hacer daño, } \\
\text { cuando estallo hecho a perder cosas. }\end{array}$ \\
\hline \multicolumn{2}{|c|}{ Categoría 3. Cadena de conductas destructivas y autodestructivas } \\
\hline $\begin{array}{l}\text { Falta de autocuidado } \\
\text { y de cuidado al otro(a) }\end{array}$ & $\begin{array}{l}\text { Un día me pidió que le ayudara a hacer un diseño en la computadora y con una reacción violenta después } \\
\text { de golpear el teclado se subió a dormir, no le dije nada, si llego tarde de trabajar comenta que tengo otra. El } \\
\text { mínimo detalle la hace explotar y a su reacción yo experimento cólera y me saca de mis casillas. }\end{array}$ \\
\hline $\begin{array}{l}\text { Falta de autocuidado, } \\
\text { desencuentros }\end{array}$ & $\begin{array}{l}\text { No acepto lo que ella me dice, por ejemplo, me dice que vaya al doctor y no voy, es muy posible que padezca } \\
\text { diabetes, no sé si es por miedo o destino, la situación es que no tomo una decisión, pierdo concentración en } \\
\text { mi situación matrimonial, estoy disperso y creo que ella también, nunca estamos juntos, en la comida tampoco, } \\
\text { en lo sexual, no son con la frecuencia que yo quisiera, me dice que está cansada, además ella padece de } \\
\text { depresión y tampoco se atiende, aunque cuando estuvo tomando medicamento me dijo que se sentía muy bien, } \\
\text { ninguno de los dos accede a tratar de integrarnos, siento que ella no quiere estar conmigo y yo tampoco quiero } \\
\text { estar con ella. }\end{array}$ \\
\hline \multicolumn{2}{|c|}{ Categoría 4. El otro vivido como enemigo } \\
\hline Descalificación & $\begin{array}{l}\text { Me siento muy mal porque estoy poniendo todo de mi parte y escuchar que mi esposa se siente decepcionada } \\
\text { piensa que soy un hipócrita, entonces soy hipócrita con todos y conmigo mismo. }\end{array}$ \\
\hline Sobreexigencia & $\begin{array}{l}\text { No me gusta hablar mal de mi señora, me siento en un bache, no soy un hombre que se arrodilla, no puedo } \\
\text { decirle nada, pero siento que por detrás ella piensa "ya te chingué". Ella no me deja hablar y me desespero, } \\
\text { entonces empieza lo clásico (mentadas de madre). }\end{array}$ \\
\hline $\begin{array}{l}\text { Arrepentimiento, } \\
\text { venganza, denigración }\end{array}$ & $\begin{array}{l}\text { Le pedí que por lo menos me dejara dormir como perro a su lado, me parece denigrante, reconozco mis erro- } \\
\text { res, ya no le gusto, ya no me quiere. }\end{array}$ \\
\hline $\begin{array}{l}\text { Impotencia, abandono, } \\
\text { incomprensión }\end{array}$ & $\begin{array}{l}\text { Estamos en reproducción asistida, ella explota por toda la situación y yo trato de apoyarla, creo que no de- } \\
\text { bemos encontrar un culpable, yo la comprendo pero ella se aísla en su mundo sin comprender que yo tengo } \\
\text { que tragarme muchas cosas, creo que el problema es que me trata como si yo fuera uno de sus hermanos, no } \\
\text { pregunta mi opinión. Siempre estoy en medio de mi familia y ella. }\end{array}$ \\
\hline
\end{tabular}




\section{ANEXO 2 \\ Segundo objetivo: Identificar indicadores, que hayan influido en el desarrollo satisfactorio/ insatisfactorio de su vida en pareja}

\begin{tabular}{|c|c|}
\hline \multicolumn{2}{|r|}{ Mujeres } \\
\hline Elementos encontrados & Unidades de análisis y relatos \\
\hline \multicolumn{2}{|c|}{ Categoría 1. Cronificación del conflicto } \\
\hline Falta de equidad & $\begin{array}{l}\text { Él debería equilibrar su horario de ayudarme en el día, eso debería salir de él y no yo hacer el papel de padre, } \\
\text { cuando nos casamos tú quedaste de encargarte del dinero y yo de la casa y de los niños, por parte de él no } \\
\text { hay ingresos constantes y me molesta que me reclame que es su tiempo, pues este dinero es para la casa. }\end{array}$ \\
\hline $\begin{array}{l}\text { Falta de equidad, } \\
\text { anulación }\end{array}$ & $\begin{array}{l}\text { Él es muy descuidado, incapaz de levantar nada, yo tengo mil cosas que hacer, sigue siendo el mismo cerrado } \\
\text { de siempre, no entiendo por qué no se da tiempo para su familia, siento que no me quiere y que no tengo de- } \\
\text { recho a enojarme porque entonces él se enoja dos veces, no hay convivencia ni plática entre nosotros, también } \\
\text { en la educación del hijo tenemos diferencias, yo pongo reglas y él las rompe. }\end{array}$ \\
\hline Distanciamiento afectivo & $\begin{array}{l}\text { Ese acorazamiento lo hace inalcanzable y es frustrante, puedo decir que tengo un marido excelente, yo soy } \\
\text { desorganizada, lo que nos acaba de amolar es el silencio, es desconfiado, al principio era cariñoso, meloso, } \\
\text { después nos empezamos a distanciar, él dice que las cosas son como son y no pueden ser de otra manera, caí } \\
\text { en el juego y empecé a guardar silencio, se vuelve una indiferencia para defenderse, nuestra intimidad física } \\
\text { es buena, no así nuestra intimidad emocional. }\end{array}$ \\
\hline $\begin{array}{l}\text { Dependencia, aislamiento, } \\
\text { anulación de la vida } \\
\text { sexual }\end{array}$ & $\begin{array}{l}\text { Siempre lo he visto como un hermano, he querido terminar con él pero él se aferra, tengo miedo de que nos deje- } \\
\text { mos porque a mi nunca nadie me ha querido, él nunca me ha permitido estar lejos de él, y ahora con el niño pues } \\
\text { más, no me siento bien con él casi nunca tenemos relaciones, siento que desde que lo conozco me ha alejado de } \\
\text { mis amigos, yo siempre lo he odiado, y siempre siento que él tiene la culpa, cuando yo me iba a casar ya estaba } \\
\text { embarazada yo no quería pero él me hizo un drama, pero el niño se murió, no somos marido y mujer. }\end{array}$ \\
\hline \multicolumn{2}{|c|}{ Categoría 2. Manifestaciones agudas del conflicto } \\
\hline Infidelidad, atrapamiento & $\begin{array}{l}\text { Me enteré que mi esposo tiene una niña, y mi primer impulso fue serle infiel, me sentí descontrolada pero decidí } \\
\text { quedarme con él, traté de imponerme para formar un hogar o para separarme definitivamente. }\end{array}$ \\
\hline $\begin{array}{l}\text { Anulación, devaluación, } \\
\text { venganza }\end{array}$ & $\begin{array}{l}\text { A él se le olvidó que yo existía, se la pasaba tomando, en una ocasión fue a dejarme al puesto de jugos, no } \\
\text { regresó por mí, todavía llegó a pedirme de comer y traía la camisa llena de besos, yo le aguantaba todo pero } \\
\text { eso no, le perdí el respeto. Lo sentencié y desde ese momento me he descarriado, hago lo que me da la gana, } \\
\text { conocí a este pretendiente, el me ayudó mucho, fue un apoyo. Él nunca se preocupó por mí, le dije que tenía un } \\
\text { pretendiente por que siempre me devaluaba, que me las iba a pagar, por eso no me he ido de la casa. }\end{array}$ \\
\hline \multicolumn{2}{|c|}{ Categoría 3. Fallas en la estructuración de la pareja } \\
\hline $\begin{array}{l}\text { Utilización, fallas } \\
\text { de estructuración, } \\
\text { abandono }\end{array}$ & $\begin{array}{l}\text { Creo que necesitamos nuestro espacio, necesitamos libertad, él siempre quiere salir solo, no le cae el veinte que } \\
\text { ya es parte de una pareja, no habla, no avisa, llega tarde, él piensa que lo quiero dominar. Cuando quiere ser } \\
\text { adulto quiere ser independiente y cuando necesita que se le hagan las cosas es un niño o corre con su mamá, } \\
\text { me hiere en la manera de cómo me habla, me ordena que haga las cosas y me utiliza, tenemos dos años juntos } \\
\text { y una tercera parte me la he pasado llorando y peleando. }\end{array}$ \\
\hline $\begin{array}{l}\text { Descalificación, } \\
\text { atrapamiento }\end{array}$ & $\begin{array}{l}\text { Dice mi esposo que me provoco las enfermedades, él puso su geta y yo pensé "ya me voy", todo el tiempo son } \\
\text { chantajes y agresiones, me dice que son cinco años de problemas que ya está harto de esta situación, él goza } \\
\text { de privilegios como irse a hacer ejercicio, y me dice que yo no me lo merezco. }\end{array}$ \\
\hline $\begin{array}{l}\text { Descalificación, } \\
\text { incomprensión }\end{array}$ & $\begin{array}{l}\text { Me excluye y además me hace sentir culpable, al bebé anterior no le hizo caso y finalmente no sabe qué hacer } \\
\text { con esta situación, me dice que yo no deseaba a la niña que él sí la deseaba, que estoy loca. }\end{array}$ \\
\hline Atrapamiento, desamor & $\begin{array}{l}\text { No me puedo quitar este odio, él ha puesto mucho de su parte, me apoya en todo, sin embargo siempre he } \\
\text { sentido esas cosas, en la vida diaria estamos bien, pero cualquier cosa me remueve el pasado, no puedo } \\
\text { olvidarlo, llevamos cinco años y seguimos dependiendo de mi familia, eso me da mucho coraje. Me manipuló } \\
\text { para dejar de salir, mis amigos empezaron a dejarme, me hace sentir como querer quitármelo de encima, } \\
\text { siento que él me los quitó. }\end{array}$ \\
\hline \multicolumn{2}{|c|}{ Categoría 4. Utilitarismo, violencia y exclusión de la pareja } \\
\hline Vacío, resentimiento & $\begin{array}{l}\text { Ha cambiado mucho conmigo, es muy cariñoso y eso me molesta porque hago una retrospección, el tiempo que } \\
\text { perdimos discutiendo injustamente y peor me siento cuando habla en sesión, creo que se exhibe como une persona } \\
\text { buena y juicioso cuando él nunca fue así conmigo, me hizo pesada la vida y tengo rencor conmigo por haberlo } \\
\text { permitido, creo que esto lo vivimos durante } 18 \text { años, pero ahora he sacado mi fuerza y ante cualquier situación me } \\
\text { molesto y grito, creo que esto le duele mucho. }\end{array}$ \\
\hline Utilización & $\begin{array}{l}\text { Desde que nos casamos, lo que había de novios ya no existe, percibo mal mi sexualidad, me siento como un } \\
\text { mueble ya no tengo ganas de levantarme, si él me dice, me voy, que se vaya. }\end{array}$ \\
\hline
\end{tabular}




\section{ANEXO 2 (continuación)}

\begin{tabular}{|c|c|}
\hline $\begin{array}{l}\text { Dependencia, } \\
\text { atrapamiento, falta } \\
\text { de cuidado, agresión } \\
\text { cotidiana }\end{array}$ & $\begin{array}{l}\text { Antes mi salud no me preocupaba, ahora me preocupo, mi esposo siempre me hecha en cara los gastos por mis } \\
\text { enfermedades. Me estoy consumiendo, no puedo tomar decisiones, dependo de mi esposo, está enojado por que la } \\
\text { tlapalería no está a su nombre, sino al mío; no se como dialogar con mi esposo ya se pasaron los límites, el siempre } \\
\text { me responde con agresiones. }\end{array}$ \\
\hline $\begin{array}{l}\text { Vacío, explotación, } \\
\text { pobre autocuidado }\end{array}$ & $\begin{array}{l}\text { Estoy muy enojada, lo más doloroso para mí es que mi pareja no me apoya y todo mundo se da cuenta menos } \\
\text { yo. No me demuestra afecto, llevo siete años con calambres, no puedo hablar bien, todos mis sentidos están } \\
\text { bloqueados él no me toma en cuenta, no quería que viniera, fracasamos, volvemos a salir, actualmente estamos } \\
\text { rentando. Pusimos un negocio en el que yo soy empleada y también mi mamá, no recibimos sueldo y no hay } \\
\text { ganancias, él no ve que yo rinda y está molesto, el día que me va muy bien él dice préstame todo lo que hay, } \\
\text { para mi es muy duro que no me tome en cuenta y sigo esperando, no se dónde está mi fortaleza, hay un miedo } \\
\text { a que él me juzgue, estoy atorada. }\end{array}$ \\
\hline $\begin{array}{l}\text { Devaluación, utilización, } \\
\text { objeto sexual, aislamiento }\end{array}$ & $\begin{array}{l}\text { Creo que desde que somos novios mis problemas de autoestima se han agravado. Él siempre fue el guapo, } \\
\text { el que todas querían con él yo venía de un divorcio y tenía una niña, yo no entraba en su prototipo de mujer. } \\
\text { Cuando estaba embarazada de nuestro primer hijo y vivíamos juntos decía que seguíamos siendo amigos. Para } \\
\text { mí era un sueño estar con él y ahora se ha convertido en una pesadilla. En lo íntimo también es muy egoísta y } \\
\text { muchas veces me siento utilizada. Me volví muy huraña, no salía de mi cuarto por que no me sentía a gusto, } \\
\text { me la pasaba llorando por que él no me daba afecto, es un tormento salir con él porque voltea a ver a todas } \\
\text { las mujeres, a mi no me admira, no me ve, dice que yo soy una mujer de seis y que muchas mujeres quisieran } \\
\text { estar en mi lugar. }\end{array}$ \\
\hline Indiferencia, desamor & $\begin{array}{l}\text { Dejé de pelear, me volví indiferente, yo siempre he trabajado y me propuso que pusiéramos un negocio, le } \\
\text { dije que no, yo he trabajado menos y lo hago por que quiero que él se dé cuenta de lo que vale mi trabajo, } \\
\text { terminaba haciendo lo que él quería, le dije me diste en la madre y ahora me intereso yo. }\end{array}$ \\
\hline \multicolumn{2}{|c|}{ Categoría 5. Distintos procesos destructivos } \\
\hline Violencia y sumisión & $\begin{array}{l}\text { Llega mi esposo saluda, cuando come hay que atenderlo rápido, le digo a mi esposo ¿̇ya te sirvo de comer? Y } \\
\text { él me dice "chingada madre, sabes que no me gusta comer cuando hay gente", siempre mi esposo levanta la } \\
\text { voz, desde el jueves empezó mi tristeza, yo siempre le digo "tu siempre me maltrataste", veo todo eso y siento } \\
\text { mucho coraje y rencor. Yo engañé a mi esposo, pero le dije "perdóname no lo vuelvo a hacer", él me dice que } \\
\text { soy lo peor que no valgo. }\end{array}$ \\
\hline Violencia & $\begin{array}{l}\text { Me golpea, le mencioné que la próxima vez me largo a la delegación y lo demando, él dice que la que está } \\
\text { mal soy yo, antes me quedaba callada, él ya me dijo que no lo demando porque primero me mata. }\end{array}$ \\
\hline $\begin{array}{l}\text { Celos, fallas de estructura } \\
\text { de pareja }\end{array}$ & $\begin{array}{l}\text { Mi problema son los celos, el problema empezó cuando él se fue a rentar un cuarto solo. Mi pareja me dijo que } \\
\text { me fuera a vivir con él, pero yo no me he querido ir porque no quiero dejar a mi hijo y él no quiere venir con no- } \\
\text { sotros, sus primos le dicen que yo no lo quiero, ahora ha empezado a tomar y dice que es por mi culpa, mis celos } \\
\text { empezaron a partir de que mi marido se salió de la casa, el pensar que está solo me hace imaginarme cosas. }\end{array}$ \\
\hline Violencia & $\begin{array}{l}\text { Me sacó de mis casillas y llegamos a las cachetadas, me molesta que me cuide, durante } 13 \text { años se la pasó } \\
\text { tomando y ahora resulta que me cuida, eso es ser hipócrita, en septiembre termina su juramento y va a caer en lo } \\
\text { mismo, dice que si me voy me voy con las manos vacías porque nada es mío todo es de él. }\end{array}$ \\
\hline \multicolumn{2}{|c|}{ Categoría 6. Carencias en la vida afectiva } \\
\hline $\begin{array}{l}\text { Vacío existencial, fractura } \\
\text { de pareja distanciamiento } \\
\text { afectivo }\end{array}$ & $\begin{array}{l}\text { Me hicieron una histerectomía hace tres años, veo a mi esposo como mi bebé, no tengo a nadie más a quien } \\
\text { cuidar, siento que no sirvo, tengo que buscar para qué servir. Mi hijo tiene problemas de conducta, empeza- } \\
\text { mos a buscar ayuda y actualmente mi esposo ya no me acompaña, me siento muy angustiada, hay muchos } \\
\text { problemas en mi casa. Tenemos problemas por la educación de nuestro hijo, él me contradice, no apoya las } \\
\text { decisiones. Mi reclamo es que siempre fue cariñoso y dejó de serlo, por eso yo transformé toda mi atención } \\
\text { para con mis hijos. }\end{array}$ \\
\hline $\begin{array}{l}\text { Atrapamiento, } \\
\text { fallas de estructuración, } \\
\text { anulación del otro }\end{array}$ & $\begin{array}{l}\text { La situación económica es pesada porque no cobra, esto lleva años y a mí últimamente no me ha ido bien con } \\
\text { la venta de ropa, le digo que sí lo quiero pero no estoy segura que él me quiera. No sé qué más espera de } \\
\text { mí, no le gustan las obligaciones, todo de mí le molesta, es déspota conmigo, mi presencia está de más. No } \\
\text { quiero darle al bebé una vida sin padre, creo que lo único que puede alegarme es mi carácter explosivo, estoy } \\
\text { esforzándome por moldear mi carácter. }\end{array}$ \\
\hline
\end{tabular}




\section{ANEXO 2 (continuación)}

\begin{tabular}{|c|c|}
\hline \multicolumn{2}{|r|}{ Hombres } \\
\hline Elementos encontrados & Unidades de análisis y relatos \\
\hline \multicolumn{2}{|c|}{ Categoría 1. Fallas en la estructuración de la pareja y cronificación del conflicto } \\
\hline $\begin{array}{l}\text { Incongruencia, culpa, } \\
\text { dificultades al cambio } \\
\text { de vida }\end{array}$ & $\begin{array}{l}\text { Ese paso de soltero al matrimonio es sumamente complicado, cuando te casas todo cambia, no existe la cos- } \\
\text { tumbre de estar en casa temprano, para mí ese ajuste fue sumamente complicado, sentía mi libertad cortada, } \\
\text { siento que uno es inmaduro. }\end{array}$ \\
\hline $\begin{array}{l}\text { Anulación, fallas } \\
\text { en la estructuración } \\
\text { de pareja }\end{array}$ & $\begin{array}{l}\text { Ella me ayuda pero después me lo echa en cara, dice que mi familia, pero ella también está con su familia, en } \\
\text { Semana Santa se fue y yo tuve que ir porque se llevó al niño, ella me pasa por alto, yo no sé cómo ponerle los } \\
\text { límites. Nunca debió de casarse conmigo, nos fuimos } 20 \text { días con mis suegros cuando tuvo a la bebé, ella como } \\
\text { una niña chiquita con su mamá, somos dos, ella no está dispuesta a depositar su confianza en mí. }\end{array}$ \\
\hline Atrapamiento, impotencia & $\begin{array}{l}\text { Desde que nació mi niña, mi vida ha cambiado completamente, se molesta por muchas cosas se enoja por todo, } \\
\text { esto me hace preguntarme qué debo hacer. Creo que es cuestión de paciencia. }\end{array}$ \\
\hline $\begin{array}{l}\text { Problemas con el proceso } \\
\text { de individuación, } \\
\text { demanda, } \\
\text { celos, posesividad }\end{array}$ & $\begin{array}{l}\text { Yo no quería perder mi libertad porque no me daba ningún espacio para mí, siempre se ponía triste si no } \\
\text { estaba con ella. Ella me retenía cuando estaba más enojado en vez de dejarme ir, provocando que explotara, } \\
\text { me detenía para seguir diciéndome cosas. El problema lo disparan sus celos y posesividad, cualquier cosa es } \\
\text { motivo, lo entiendo porque existió un problema muy grande con otra mujer. No puedo estar en mi casa, prefiero } \\
\text { refugiarme en mi trabajo. Ella se la pasa llorando, no me permite despegarme ni un solo momento. }\end{array}$ \\
\hline $\begin{array}{l}\text { Falta de entendimiento, } \\
\text { desencuentro }\end{array}$ & $\begin{array}{l}\text { Yo también soy de carácter explosivo. Adoptamos un sistema en donde ella paga hasta que a mi me paguen, } \\
\text { pero cuando se enoja me echa en cara las cosas. }\end{array}$ \\
\hline $\begin{array}{l}\text { Fallas en la organización, } \\
\text { caos }\end{array}$ & $\begin{array}{l}\text { La semana pasada tratamos de poner orden a nuestras actividades de pareja. Lo empezamos a hacer y luego } \\
\text { nos salimos de ese orden. Por detalles nos desesperamos. Llegamos a tener un conflicto por X cosa de la casa } \\
\text { y tratamos de no enfrascarnos en la riña, cuando no tengo razón me quedo callado, se me hace complicado. } \\
\text { Oye esto o el otro quizá decirle eso sea mi error y ella ya me contesta, a lo que quiero llegar es que para ella } \\
\text { está primero el trabajo y después están mis hijos, pero a ella no le gusta estar encerrada en cuatro paredes, } \\
\text { trabajar en la casa. Trato de tener hábitos de horario para los niños, es que a mí se me hace difícil expresarme, } \\
\text { me da coraje. }\end{array}$ \\
\hline \multicolumn{2}{|c|}{ Categoría 2. Manifestaciones cotidianas de violencia } \\
\hline $\begin{array}{l}\text { Venganza, violencia } \\
\text { en escalada simétrica }\end{array}$ & $\begin{array}{l}\text { Yo vine aquí porque tenía problemas de alcohol, durante tres años trate mal a mi esposa, ella tenía un pretendiente, } \\
\text { siempre he tenido esa espina de celos, yo una vez llegué con la camisa pintada, ella se vengó durante tres años, yo } \\
\text { trabajo en seguridad, dejé de tomar y ahora ella es la que está tomando, viene bien cruda. No se si tengo celos, lo } \\
\text { que me molesta ahora son las borracheras que se pone. }\end{array}$ \\
\hline $\begin{array}{l}\text { Devaluación, celos, } \\
\text { conductas destructivas }\end{array}$ & $\begin{array}{l}\text { Siempre que le levanto la mano es provocado, en la intimidad dos veces me confundió con el otro señor, ella } \\
\text { se puso a tomar y yo me fui, cuando la conocí yo tenía } 15 \text { años, en ella encontraba mucha paz, ella empezó } \\
\text { a sentirse vieja y los problemas no han parado, para ella yo todo lo hago mal, de hablarme amorosamente } \\
\text { ahora o de pronto me arremete, cuado esto sucede empiezo a enojarme, antes de levantar la mano ya recibí } \\
\text { múltiples agresiones, me sentí muy lastimado cuando me confundió con el otro, no se cansa de decirme que } \\
\text { esto es lo peor. }\end{array}$ \\
\hline Reflexión & $\begin{array}{l}\text { Yo también fui muy violento. Afortunadamente encontré el arte como escape, si no canalizo todo este odio no } \\
\text { sé que pasa; ojala y encontráramos una fórmula aquí para poder aceptar que estamos mal. Le estoy echando } \\
\text { muchas ganas por que tengo la necesidad de ser agresivo, quiero demostrarle que la amo, la quiero y la necesito, } \\
\text { pero soy muy pendejo y no sé cómo; ella me ha enseñado a trabajar. }\end{array}$ \\
\hline $\begin{array}{l}\text { Las diferencias son } \\
\text { conflicto }\end{array}$ & $\begin{array}{l}\text { El grito es por situaciones extremas, avanza el tiempo y no se resuelven las cosas, en ocasiones quieren que } \\
\text { entendamos por telepatía. Me pasa algo que creo que les pasa a todos, que tenemos patrones que no les } \\
\text { gustan a nuestra pareja. }\end{array}$ \\
\hline $\begin{array}{l}\text { Violencia, devaluación, } \\
\text { abuso }\end{array}$ & $\begin{array}{l}\text { A los dos nos unió la soledad, entonces nos casamos y pensamos tener un bebé. Ya estando casados me dijo } \\
\text { que por qué no vives tú en tu casa y yo en la mía y nos vemos en ocasiones y le dije que así no era un matrimo- } \\
\text { nio y le dije que mejor nos separáramos. Ella me decía tú nunca vas a ser como esa persona que tenía antes, la } \\
\text { miré a los ojos y le dije que yo no necesitaba ser otra persona y seguí caminando, se molestaba y me golpeaba } \\
\text { y pues yo llegó un momento en el que me desesperé. Yo estoy bien pero por qué me golpea, jeh! Y ya empece } \\
\text { a decirle sabes que soy hombre pero no soy tonto y llegó un momento en que decidí usar preservativo, no voy } \\
\text { a tener un hijo con esta persona. }\end{array}$ \\
\hline
\end{tabular}




\section{ANEXO 3 \\ Tercer objetivo: Identificar elementos que dentro de la dinámica familiar nuclear impactaron o impactan su vida actual de pareja}

\begin{tabular}{|c|c|}
\hline \multicolumn{2}{|r|}{ Mujeres } \\
\hline Elementos encontrados & Unidades de análisis y relatos \\
\hline \multicolumn{2}{|c|}{ Categoría 1. Abuso sexual en la infancia por descuido familiar } \\
\hline $\begin{array}{l}\text { Falta de protección } \\
\text { y cuidado }\end{array}$ & $\begin{array}{l}\text { Uno de mis vecinos nos bajaba los calzones y nos tocaba los genitales, lo que me molesta es la actitud de mi } \\
\text { padre cuando se enteró, pues lo saluda. Otro vecino me mostró su miembro y quería que lo besara, por parte } \\
\text { de mi madre no me sentí descuidada, era una mujer muy trabajadora que se daba a su familia, mi papá era } \\
\text { muy miserable, mi mamá era normal. }\end{array}$ \\
\hline $\begin{array}{l}\text { Abuso sexual complicado } \\
\text { con incesto }\end{array}$ & $\begin{array}{l}\text { Quiero hablar hoy, siempre en mi familia hubo pleitos, golpes. Mi abuelo trató de abusar de mí y yo le dije a } \\
\text { mi mamá y ella sólo dijo que no le fuera a decir a mi papá, yo me sentía sucia y me echaba la culpa, mi abuelo } \\
\text { había intentado hacerlo con todas mis hermanas, yo pensé que eso era normal y que yo había tenido la culpa. } \\
\text { Cuando llegué a la adolescencia no me dejaba ponerme lo que me gustaba porque me veía sucia. Cuando tuve } \\
\text { mi segundo novio mi papá me dijo que era una puta aunque yo me portaba bien, entonces dije: sí voy a ser una } \\
\text { puta y me acosté con el que ahora es mi esposo, yo tuve un orgasmo como dos años después de casarme, plati- } \\
\text { cando con mi hermana me doy cuenta que esto nos afectó nuestra sexualidad, nuestra vida de casados, cuando } \\
\text { mi esposo tenía tensiones con su familia yo me ponía muy molesta, esto es porque yo quería que me cuidara a } \\
\text { mí. Me doy cuenta que odio a mi mamá y aun así estoy repitiendo los patrones de ella, esta es una conducta } \\
\text { muy egoísta, la recuerdo golpeándome y con la responsabilidad de que yo cuidara a mis hermanos. }\end{array}$ \\
\hline $\begin{array}{l}\text { Abuso sexual } \\
\text { con repercusiones } \\
\text { en la vida adulta }\end{array}$ & $\begin{array}{l}\text { Fui abusada a los } 5 \text { años por un tío, la semana pasada tuvimos una reunión familiar y mi esposo le dio a la niña } \\
\text { a este tío y sentí coraje, me da terror que mi hija esté en brazos de cualquier hombre que no sea mi esposo. } \\
\text { Siempre tengo desconfianza de todos, con el único que me siento bien es con mi esposo, pero siento que ya } \\
\text { no somos pareja y no lo puedo dejar. }\end{array}$ \\
\hline $\begin{array}{l}\text { Violación, miedo, deva- } \\
\text { luación }\end{array}$ & $\begin{array}{l}\text { A mí me violaron cuando tenía } 6 \text { o } 7 \text { años un hermano de mi papá, desde entonces fui agredida, nunca se lo dije } \\
\text { a mi mamá y pensé que nunca lo iba a decir por pena. Creía que la virginidad era importante y como yo no era } \\
\text { virgen pensé que tenía que aguantarme, soy la bruja del cuento. }\end{array}$ \\
\hline $\begin{array}{l}\text { Abuso sexual, descuido } \\
\text { familiar, violencia }\end{array}$ & $\begin{array}{l}\text { Yo también fui violada a las } 12 \text { años por un amigo de mi hermano y salí embarazada, me amenazó con pistola } \\
\text { y eso duró seis meses, sentí que mi mamá no me dio el cuidado necesario y siento que me está pasando lo } \\
\text { mismo con mi hija de } 11 \text { años y una doctora me dijo que mi hija ya había sido tocada. }\end{array}$ \\
\hline $\begin{array}{l}\text { Abuso sexual } \\
\text { en la infancia } \\
\text { con repercusiones en su } \\
\text { vida de pareja actual }\end{array}$ & $\begin{array}{l}\text { Fui abusada a los } 7 \text { años por el esposo de mi hermana, mi papá tomaba, mi mamá nunca estaba, él golpeaba } \\
\text { a mi hermana, encontré refugio en el estudio y en la iglesia, yo le dije a mi hermana lo que había pasado, ella } \\
\text { se separó. Yo le dije todo esto a mi esposo, él me pegó, me insultó, embarazada me pregunté para qué vivía, } \\
\text { él siguió tomando, los que toman me dan miedo, ahora le he puesto límites a mi marido, él no me miraba, no } \\
\text { me tocaba, dejé mi trabajo por él, se responsabilizó, el ya se acerca a mí. }\end{array}$ \\
\hline $\begin{array}{l}\text { Abuso sexual, } \\
\text { descuido familiar }\end{array}$ & $\begin{array}{l}\text { Mi mamá jamás me hizo caso, me violó uno de mis hermanos, nunca me han dejado decirle a nadie, mi papá } \\
\text { sabe, parece que también abusó o trató de abusar de mi hermana. Mi papá rapó a mi hermana de castigo, } \\
\text { tenía yo } 8 \text { años, jamás nos tomaron en cuenta como mujeres. }\end{array}$ \\
\hline \multicolumn{2}{|c|}{ Categoría 2. Carencias afectivas infantiles } \\
\hline $\begin{array}{l}\text { Ruptura de jerarquía } \\
\text { alianzas, manipulación }\end{array}$ & $\begin{array}{l}\text { Para mi mamá era más fácil tenerme que enfrentarlo, me duele que ella haya querido que fuéramos enemigas de } \\
\text { mi padre, ella busca esa conflictividad entre hermanos, por permitir cosas y no poner límites, cuanto más sufría } \\
\text { era más madre. }\end{array}$ \\
\hline $\begin{array}{l}\text { Activación } \\
\text { en la relación de pareja }\end{array}$ & $\begin{array}{l}\text { Tuve una infancia muy difícil, estuve sola, cuando él se porta como se porta me hace recordar las cosas que yo viví. } \\
\text { No recuerdo una caricia o un abrazo de mi mamá, ahora busco cambiar las cosas y estar con ellos, les resuelvo los } \\
\text { problemas, siempre me he sentido muy sola y tengo miedo a no tener compañía, a no tener un poco de cariño. }\end{array}$ \\
\hline \multicolumn{2}{|c|}{ Categoría 3. La familia nuclear antes que la familia actual } \\
\hline Fallas en la jerarquía & Él no me da mi lugar, siempre defendiendo al hermano y a la esposa del hermano. \\
\hline Dependencia familiar & No podemos desligarnos de su familia, vivimos arriba de sus papás. \\
\hline Fractura de pareja & $\begin{array}{l}\text { Tuvimos una boda de la familia de él, nos peleamos porque al bebé lo agarraban con las manos sucias, él } \\
\text { nunca ha resuelto nada, nunca me has defendido, ahora ni a tu hijo, yo he sacado la casa a flote porque él } \\
\text { no tiene sueldo fijo, mi dinero si lo acepta, su familia está antes que yo, ya me cansé. Siempre dices que yo no } \\
\text { tengo la razón que soy una desquiciada, porque él es siempre el ecuánime, si soy la loca mejor me largo. }\end{array}$ \\
\hline $\begin{array}{l}\text { Fractura de pareja, } \\
\text { dependencia familiar }\end{array}$ & $\begin{array}{l}\text { Él no es responsable y además mal proveedor, él dice que lo que gana es para su familia no para mí, después } \\
\text { de la pelea ya no quería nada con él ni siquiera sexo, siento que sólo me ha usado como un desahogo sexual, } \\
\text { quisiera tener la fortaleza de rechazarlo, tengo un miedo terrible de volver a embarazarme. }\end{array}$ \\
\hline
\end{tabular}




\section{ANEXO 3 (continuación)}

\begin{tabular}{|l|l|}
\hline Incomprensión & Mi familia es muy apegada a mí y hablando del egoísmo bueno, mi marido se molesta porque les resuelvo la vida a
\end{tabular} mis hermanos, eso me parece muy egoísta de su parte porque no estoy dejando de hacer nada.

\begin{tabular}{|c|c|}
\hline \multicolumn{2}{|r|}{ Hombres } \\
\hline Elementos encontrados & Unidades de análisis y relatos \\
\hline \multicolumn{2}{|c|}{ Categoría 1. Violencia en el núcleo primario y sus repercusiones en la vida actual } \\
\hline Intrusión & $\begin{array}{l}\text { De recién casados le pegué a mi papá, hubo problemas entre mis hermanos, le pegaron a ella (a la esposa) y } \\
\text { la defendí y nos corrieron, de ahí empecé a tomar, él siempre me ayudó mucho, después lo seguí viendo y le } \\
\text { pedí perdón, últimamente lo he recordado mucho, un padre siempre hace falta. }\end{array}$ \\
\hline Violencia familiar & $\begin{array}{l}\text { Mi padre era de un carácter tremendo, se cegaba, en un periodo de mi niñez me alejé de él, no tuve ese acer- } \\
\text { camiento, experimentaba la cólera cuando le pegaba a mi mamá. Mi hermano y yo conseguimos un terreno } \\
\text { vacío en donde hicimos una choza, después llegó mi madre y en una ocasión le propinó un tabicazo en la } \\
\text { cabeza, yo la curé y empecé a agarrarle odio, él me corrió de la casa, en los últimos años intenté acercarme a } \\
\text { él, estas son cosas que me duelen, siempre he querido ver cosas ideales, cosas calmadas, paz y no agresión. } \\
\text { Soy necio, no entiendo las cosas que ella me dice, soy malo dentro de mi matrimonio, para ella soy lo peor. }\end{array}$ \\
\hline Vacío existencial & $\begin{array}{l}\text { Me siento muy mal, perdí mi juventud porque siempre tuve que jugar un rol que no me correspondía, cuidando } \\
\text { a mi madre, yo carezco de afecto, soy un hombre hueco, le tengo mucho miedo a la soledad, no puedo vivir } \\
\text { solo, me aguanté toda la vida y me convertí en una olla de presión. Me siento arrinconado, sólo estoy pidiendo } \\
\text { lo que yo estoy dando, soy dependiente de ella, me hace falta ella a mí. }\end{array}$ \\
\hline Proceso destructivo & $\begin{array}{l}\text { Tratando de buscar el por qué y el cómo, entiendo que eso de no hablar es aminorar la presión que existe } \\
\text { dentro de la pareja, después es una barrera tan alta que nos hace ver, aquí no pasas, ahí vienes y con eso } \\
\text { te friego. Esto directamente hacia mi esposa, muchas veces la utilizo para desquitarme de lo que fue mi vida } \\
\text { anterior, no quiero que sepan cómo fue mi vida, la ganancia que tiene uno cuando friega al otro es sentirse } \\
\text { superior y además uno lo cree. }\end{array}$ \\
\hline \multicolumn{2}{|c|}{ Categoría 2. Carencias infantiles y su repercusión en su familia actual } \\
\hline Carencias infantiles & $\begin{array}{l}\text { Yo me siento solo. Hoy ya soy huérfano, yo le daba el gasto a mi mamá a mi papá. Nunca tuve a la persona } \\
\text { para decirme estás trabajando para el futuro, para que tengas las herramientas suficientes para tener la calidad } \\
\text { de vida y dárselas a tus hijos, a mí nadie me dijo nada. Lo que más me molesta es que tengamos conflictos } \\
\text { delante de mis hijos. Mi hijo de dos años y medio cuando nos peleamos me empieza a pegar por que defiende } \\
\text { a la mamá. A ella no le gusta cómo hago las cosas, yo hago las cosas y no le gusta como le hago. }\end{array}$ \\
\hline Problemas del pasado & $\begin{array}{l}\text { La llegada del bebé me mueve, ya que yo tengo un problema grave, mi madre al estar embarazada de mí fue } \\
\text { abandonada por mi padre, todo esto me regresa al resentimiento hacia mi padre, me afecta mucho esto de las } \\
\text { infidelidades. El nacimiento del bebé sólo sacó a flote los problemas anteriores, cuando nació mi otra hija perdí } \\
\text { la relación con mi esposa, ya no hay vida en común. }\end{array}$ \\
\hline \multicolumn{2}{|c|}{ Categoría 3. El pasado actualizado en la vida actual de pareja } \\
\hline $\begin{array}{l}\text { Problemas del pasado } \\
\text { no resueltos }\end{array}$ & $\begin{array}{l}\text { Su papá era alcohólico y no aportaba nada a su casa, ahora piensa que si tomo una copa me voy a volver } \\
\text { alcohólico. }\end{array}$ \\
\hline
\end{tabular}

